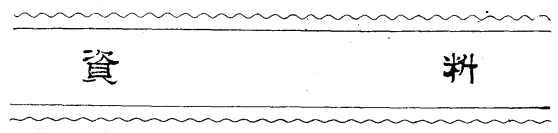

\title{
陶磁器關係技術官會議
}

和 泉 正 光

商工省主催本年度の陶磁器技術官會議は去る 5 月 5 日より 4 日間㴚器の都侭賀縣有田町に於て開催された。 有田町に於ては吉例の年 1 司の陶器市が 5 月 1 日より一週間開催されてるた折柄とて當地に於ける會議開催 は誠に時宜を得たものであつて, 出席技術者並に該地當業者に裨盆する所大なるものがあり。且又此種技術官 會詮として中央を嗃く離れた遠隔の地に於ける開催も劃期的試みとしてであつたが大成功裡に終始することを 得た。斯る成功の由因は出席技鿉官の熱意ある協力並に開催地官民の絕大なる後援による赐物である。出席找 術官は內地各道府縣並に朝鮮，臺灣に及び出席者總數 60 名に達寸る盛況であつた。(會議姴綱は本誌 5 月號 所載に付參照せられ度し。)

\section{1. 出席者名}

\begin{tabular}{|c|c|c|c|c|c|c|c|}
\hline 北海道 & 工業試驗場 & 技 & 中根 俊雄 & 青 森 & 工業試驗場 & 墑工技手 & 鹿 \\
\hline 福 島 & 工業試驗場 & 地方辟工技陑 & 小林 力 & 茨 城 & 商工水產課 & 商工技手 & 田山龺 \\
\hline 捾奈川 & 工業試驗場 & 墑 工技手 & 島岡 秀雄 & 石 川 & 工藝指導所 & 地方商工技眮 & 则恭 \\
\hline 岥 帛 & 隐磁器試驗場 & 地方墒工技㖇 & 井深 捨吉 & 岐 阜 & 陶磁器試驗場 & 商 I & 鵜飼 \\
\hline 愛 知 & 工業試驗場 & 地方商工技師 & 岩 村 新 & 愛 知 & 工業試驗場 & 地方㯆工技䧇 & 野口 \\
\hline 重 & 窯業試驗場 & 谪工菇手 & 熊澤 靖一 & 滋 賀 & 窐業試驗場 & 地方商工技阿 & 高野 \\
\hline 滋 賀 & 同 & 㓏 工莸手 & 金ヶ江德三 & 京 都 & 商 工 課 & 地方商工技阿 & 坂田 \\
\hline 京 都 & 南工業硼究所 & 技 & 中井 俊雄 & 京 都 & 甫工業㸴究所 & 技 & 高橋 \\
\hline 大阪 & 间 & 抆 & 中土 晃 & 兵 庫 & 工業試驗場 & 商 工芰手 & 渡部 斐 \\
\hline 島 根 & 工業試驗場 & 地方婮工技師 & 中野 義雄 & 岡 山 & 同 & 滴工技手 & 高才 \\
\hline 山口 & 同 & 商工技手 & 加藤 藤雄 & 香 川 & 商 工課 & 囑 & 加藤 \\
\hline 愛 蝯 & 䔵 工 課 & 商 工技手 & 小野木鐵雄 & 高 知 & 商工獎赝館 & 墑 工技 手 & 簿 \\
\hline 福 岡 & 术䈍業研究所 & 阿 & 船木 長造 & 佐 賀 & & 經 沿部 長 & 桃井 南 \\
\hline 伀 賀 & & 商 工 課 長 & 佐藤袈裂市 & 同 & 窯業試驗場 & 地方商工技師 & 一條茂喜 \\
\hline 同 & 效策試驗場 & 滴工主事補 & 朝重 健次 & 同 & 同 & 就工技手 & 田崎 \\
\hline 同 & 同 & 㓏 工技 手 & 大串喜代次 & 同 & 同 & 商 工技 手 & 德見 知 \\
\hline 同 & 案業指道所 & 商工技手 & 和中 孝男 & 同 & 窯業指導所 & 商工主事補 & 福市 \\
\hline 同 & 同 & 瓣工技手 & 澤田＼cjkstart米三 & 同 & 问 & 商 工技手 & 相川 禾 \\
\hline 崎 & & 商工倸長 & 福田＼cjkstart忠光 & 長 崎 & & 屬 & 松 本 \\
\hline 同 & 䆝業指導所 & 地方商工技陌 & 西村 交次 & 同 & 窯業指導所 & 地方 & 白 \\
\hline
\end{tabular}




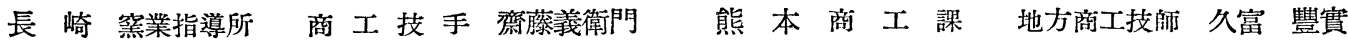
沖 繩 工業指導所技手 鈴木 利平 朝 鮮 中央試驗所技 手大橋 武夫 臺灣總督府技手狗室享

本 省 側 工業課長 西川浩, 检査課長 奧田新三, 商工屬 三上 秀, 商工技手 和泉正光, 囑託 高橋次郎

東京工業試驗所 工業試驗所技師 伊藤 亮。

陶磁器試驗所 所長 平野耕輔, 陶磁器試驗所技師 秋月 透, 同 技師 赤塚幹也, 同 技師 水町和三郎, 同技師 磯松嶺造。

\section{2. 㓱 議}

第 1 日 午前 9 時過ぎ開會の爱の後, 工務局長指示 (後揭), 工業課長說示, 陶磁器試驗所長詨明があつて, 工 業課長議長席に着き協議事項を縓めて上程し，工業課長の說明，出席技術官の意見を徽したる後，議長指名 による協議事項第 1 , 第 2 別の委員の選出あり，2 委員會成立し，次で委員長互選の爲一端休唕後委員長選 擧の報告あり第 1 委員會委員長には井深岐阜縣陶磁器試驗場長, 第 2 委員會委員長には石川縣工藝指導所小 山技師當選す，千後の日程を午前に繰り上げ昨年度會議に於て決議したる事項の報告にろつる, 議長指名に より順次報告あり，午前中に報告事項第 1 を終了す，正午休憩。午後 1 時再會報告事項第 2 及第 3 の報告艺 行ひ午後 5 時第 1 日を終る。

報 告 事 項

昭和 11 年度陶磁器技術官會議に於て決議せる事項に關する報告

（1）昭和 11 年度备地方試驗場に於て行名陶磁器に關する豫定試驗研究事項中重複又は共同の試驗研究 に關する結果の報告

（2）陶傢器工藝品に古來特有の美術を應用するが爲の具體的方法に關する報告

（3）手工の機械化及製造用機械, 裝置の改善に付具體的調查方法に關する報告 報告事項第 1 の報告者及試驗研究項は次の如し。

a 色糔 藥 の 研 究

b 低火度磁器の研究

c 魚骨をを用ふる低火度磁器の試驗

d 上繪付顏料の研究 (異色)

e 上繪付顏料の研究（鉛毒問題，無鉛繪具，優是上繪付顏䊅）

f 陶磁器用繪具に關する研究（貴金屬を主としたもの）

$\mathrm{g}$ ベントナイト粘土の利用試驗

h瓦弿に關する研究

報告事項第 2 の報告者

佐賀縣一條技師, 北海道. 中根, 技師

岐皁縣井深技師 三重縣熊澤 技 師

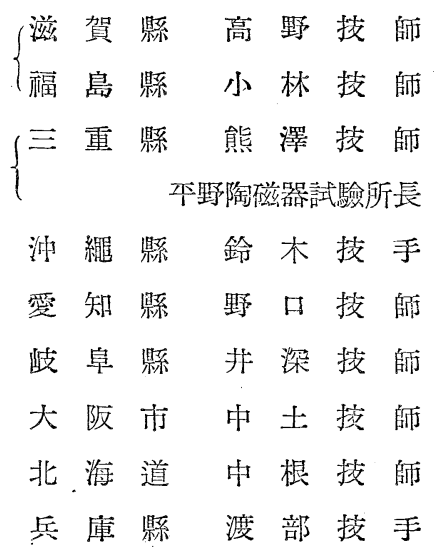

石川縣小山技師 京都市。高橋技師 


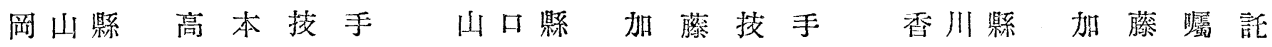

愛媛縣小野木技手長猗縣西村技師陶絁器試驗所長
報告事項第 3 の報告者

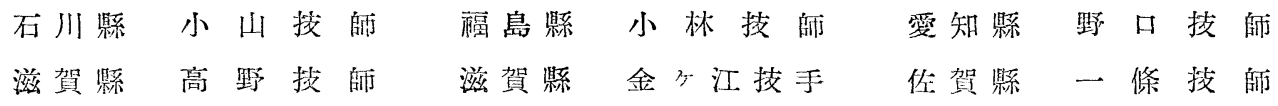

熊本縣久富技師沛繩憬鈴木技手

第 2 日 午前 9 時開會。協義事垻第 1 , 第 2 に關する委員會。正午委員會終了。午後 1 時より「輸出工藝展 試作品の製作上に關する打合會」を行ひ 3 洔斗第 2 日を終る。

協議事項並に打合事項は次の如し。

協 議 事 項

（1）昭和 12 年度各地方工業試驗場に於て行ら预定の圾驗研究事項中重複又は共通の試驗研究事項に關 する其體的連絡の䁇行方法に關する件

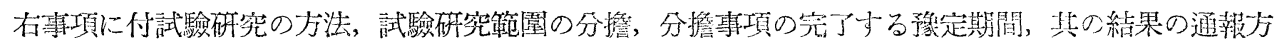

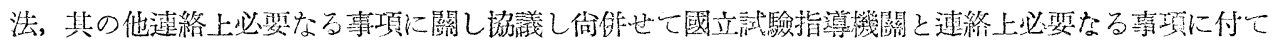
も協蟻止九とす

（2）中小陶磁器工業に於ける慜造上の改善站に能率整進に關与る件

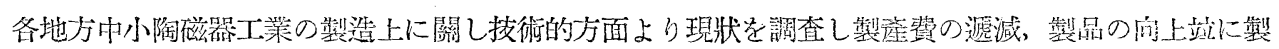

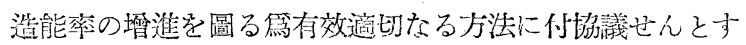

打合 揧 項

輸出工爇展試作品の製作上に閣与る作

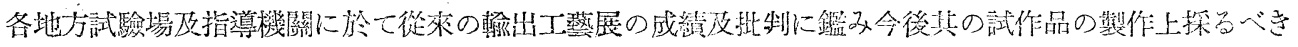
方針に付打合を行采安のと立

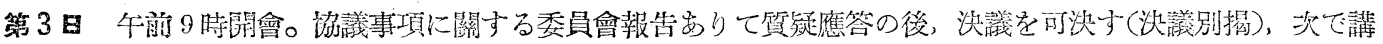

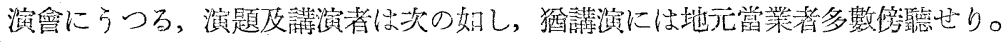

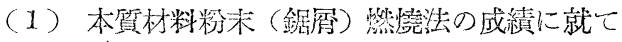

(2) 東京工業試驗所第 3 部の硒究事項に就て

(3) 泉山陣不に就て

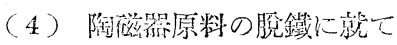

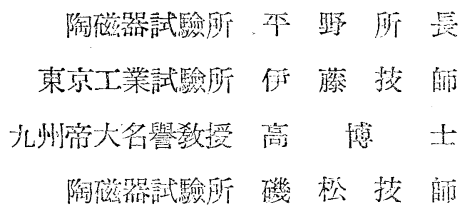

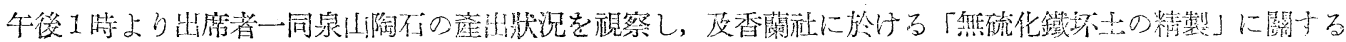
寡地指導を行ふ。

實地指導

無硫化鐵坏士の精製に關する賽地指導

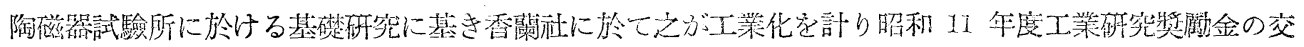

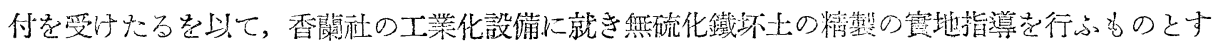

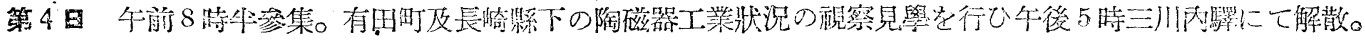
會議終了す。 
視察見學場所は次の如し。

（1）有田町 深川製磁會社，今泉今右工門，酒井田柿右工門

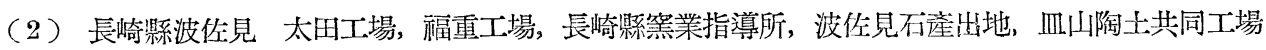

（3）三川內 公會堂，口石大八郎，長崎縣等業指導所折屁瀨分場

\section{3. 工務局長指示}

本日茲に陶磁器技術官會議を開催するに方り一言御挨㩖申上ます。各位に於ては遠路の所參集せられました ことは會議の主催者として洵に感謝に堪え奴次第であります。付きましては些か所懷の一端を述べまして御參 考に供したいと考へます。

御承知の如く各專門別に挍術官會議を開催しますことは本年で第 3 回目でありまして各位の御拹力に依り能 く所期の成果を收め斯業の伸展上多大の效果を齎しましたことは洵に欣快に壦へない所であります。

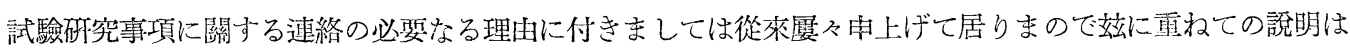
省略致しましてて此䵞に關し私の考へます所を一，二申上げ度いと存じ末す。

先づ地方工業試驗矿究機關の橫の連絡に付きましては昭和 9 年秋の試驗場長會議及 10 年, 11 年の陶嗞器 技術官會詠の際に於きましても其の主要な議題として特に每回充分御研究を願ひ夫々次年度の會議に於て其の 實施爿況の御鞋告を承り其の㙷著な效果を欣び居る次第であります。御承知の如く陶磁器關係に於ては各地方 每に原料材料等も巽り製品にも夫々特徽がありますので各地方工業試驗研究蟣關が全く步調を同じくすること は至難な事でありまして試驗研究事項の選定，其の實施上の協力には幾多の困難があることと考へますが出來 得る限り此の機會に於て充分具體的逨絡方法に付ての御協議を願ひまして將來永く緊密な連絡協力を樹立し, 各位の試驗研究及指導の效果を十二分にあげ得る樣に致し度いと存じます。

次に本省及國立試驗研究機關と地方工業試驗砰究機關との間に粲密なる縱の連絡を圖りますことは極めて必 要なるここでありまして之が本會議を開きます目的の一となつて居る次第でありますから此の機會に於て充分

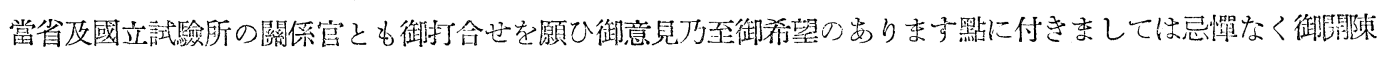
を願ひ度いと存じすす。

次に中小陶嗞器工業に於ける製造上の改善竝に能率垻進に就て申上げ度いと存じます，中小工業が我國工業 の中樞を䉆し殊に翰出工業の根澣を䉆して居ることに付ては今更多言を姴せぬ所であります，中小工業の發展 は我國情に最も適合するのでありまして今後も之を改善し，盛り立てて行くと云ふことを以て最も大きな眼目 と致さねばなら好考へるのであります。然るに現在の中小陶嗞器工業の狀熊を觀ますと製造上の技術及能率 等に於て幾多の缺陷があり之が改善を要するは目下の重要問題であるが中小陶嗞器工業者の現狀は藗だ菁資, 徽力なものが多く，自ら試驗研究を行で若くは有能な技術者を招いて其の技術的缺陷を是正するに足るの餘裕

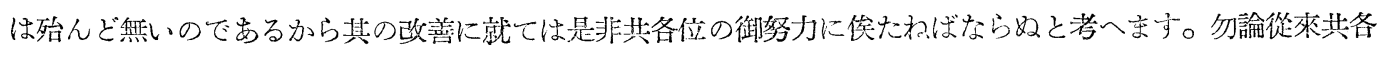
位に於ては夫々各地方の斯業の進步向上に付て御苦心になり且充分指導誘掖に努めて來られた次第であります が佮本機會に於きまして充分御協議の上有效適切なる方策を樹立せられんことを切望する次第で山ります。

以上甚だ簡單でありますが私の意のある所を察せられまして今後盆々諸般の研究改善に意を用ひられ以て我 國產業の發達に寄與せられむことを切望して已まない次第であります。

\section{4. 涹員會報告並视決議}

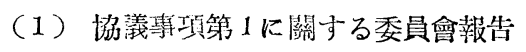


委員長 北 深 技 師

委 員 中根技師，中野技師，小林技師，加藤技手，田山挍手，田崎(木下)技手，野口技師，大串技手， 熊澤挍手，罞田技手，高野技師，鈴木技手，高橋技師，中土技師

委員外參加者 平野所長, 仾藤技師, 秋月技師, 䂺松技師

昭和 12 年度各地方試驗場に於て行ふ陶抄器に關する预定試驗㸴究事項中重複又は共同の試驗研究事項に關 乙協議の結果具體的の連絡實行方法を下記の如く協議せり。

\begin{tabular}{|c|c|c|c|c|c|}
\hline 試驗 㘧 & 試驗碑究の方法 & 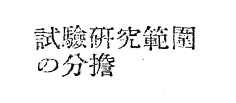 & 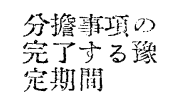 & 通街方法 & 速緦上必瑟なる烈項 \\
\hline $\begin{array}{l}\text { 低火度磁器の } \\
\text { 研究 (繼續) }\end{array}$ & 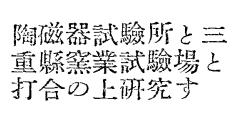 & 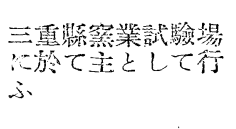 & 13 华 3 月末 & $\begin{array}{l}\text { 印剔物に } \\
\text { て码留 }\end{array}$ & 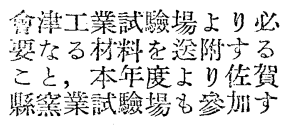 \\
\hline 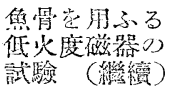 & 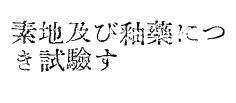 & 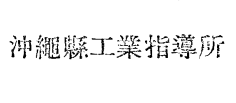 & 13 生 3 月术 & 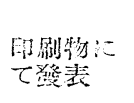 & 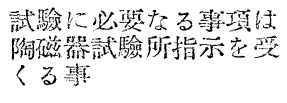 \\
\hline \multirow{2}{*}{ 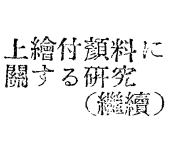 } & 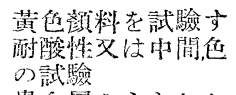 & 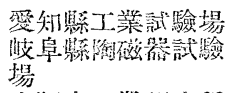 & 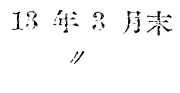 & 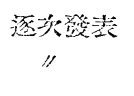 & \multirow{2}{*}{ 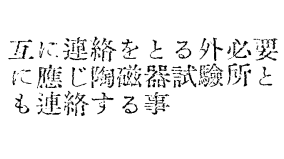 } \\
\hline & 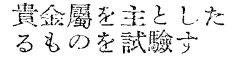 & 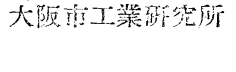 & " & " & \\
\hline $\begin{array}{l}\text { ベントチイト } \\
\text { 粘土の利间試 } \\
\text { 驗 (繼續) }\end{array}$ & 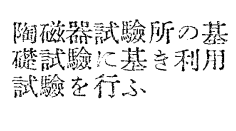 & 北游道工箖試驗場 & 1:3 3 林 & 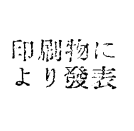 & 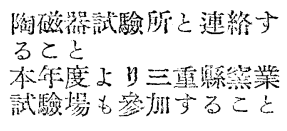 \\
\hline 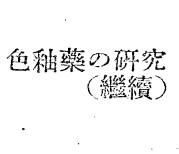 & 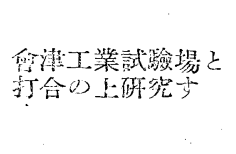 & 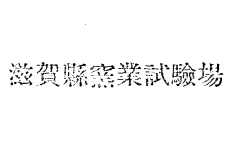 & 13 但 11 末 & 还次淡表 & 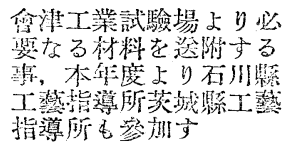 \\
\hline 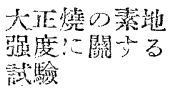 & 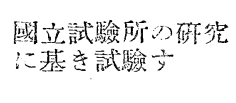 & 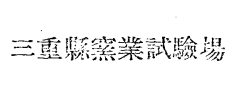 & 13 年 3 月米 & 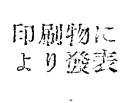 & 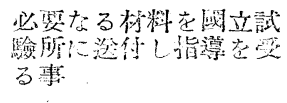 \\
\hline 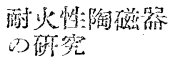 & 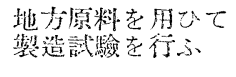 & 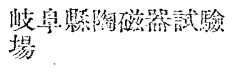 & 13 此哭 & 邀矢谈表 & 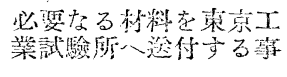 \\
\hline 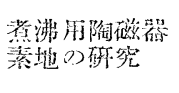 & 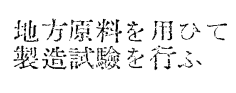 & 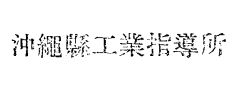 & 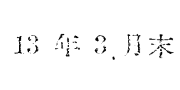 & 透大筑表 & 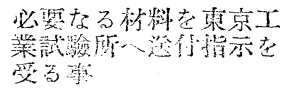 \\
\hline
\end{tabular}

倠望事項

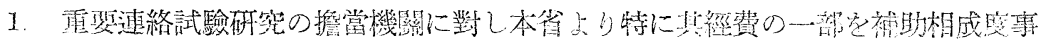

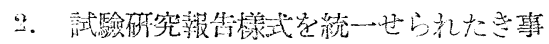

3. 瓦筧の改善を國立の試驗所に於て施行也られたき害

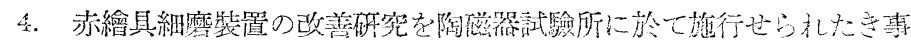

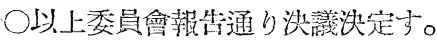

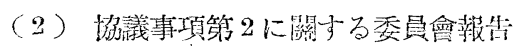

委員長 小屾拉 阨(不川)

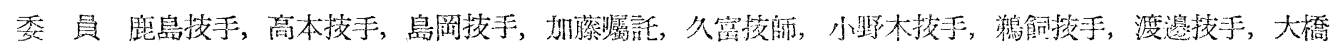

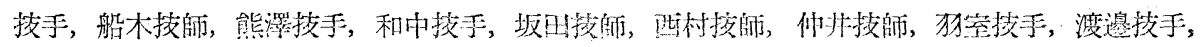
齊藤技手 
委員外參加者 平野所長, 赤塚技師

中小陶磁器工業に於ける製造上の改善站に能率霄進に關する件下記の如く協議せり。

能率の增進に於ては勉めて生產に關する調査をなし之れが調査指導は各府縣指導機關が勉めて之れに當るべ きものとす。以上調査をなすと同時に下記項目に對して之れが實施に勉むること。

1. 既設工業組合の事業に對しては盆々進儿で强化を計り未設の地方に對しては工業組合の設立を促淮せし むる事

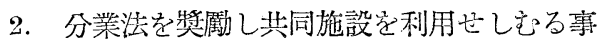

3. 特然の工程を除くの外可成簡易なる機裓化の普及を計らしもる專

希 望 事 項

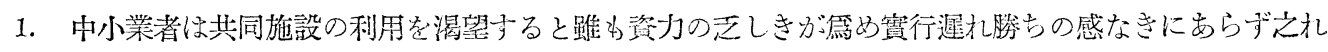
に對して當局は可度的の支援を與へられん京を希望与

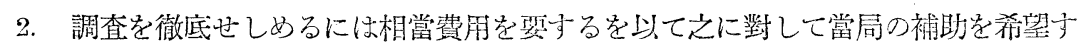

○上上委員會赤告通り決議決定寸。

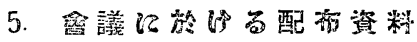

(1) 工務局の分

1. 會議亚網及日程, 出席荅名簿

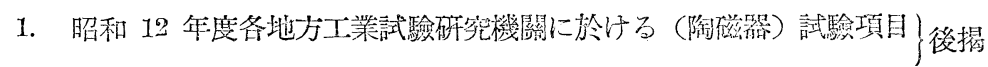

1. 昭和 12 年度國立試驗所 (陶磁器關係) 研究項目

1. 協議事項第 1 資料試驗研究項目の分類

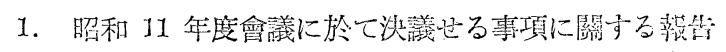

1. 道府縣才垃の商品陳列所工業試驗場度工業講甭所热定

（2）貿易局の分

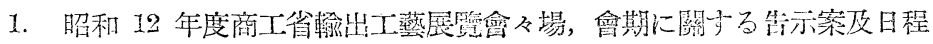

1. 日本工櫒品シカゴ涑列會以關する蓓聞記事

1. フランスに於ける陶嗞潞に就て

(3) 陶磁噼試驗所の分

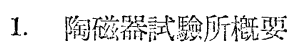

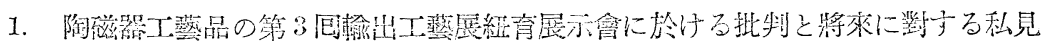

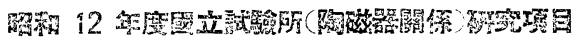

東京工業試踰所第三部研究事工具

1. ゼーゲル溫度計の慜造灭研穵

2. 急熱急冷に對し安定なる陶嗞器の碑究

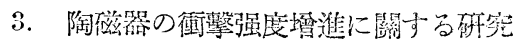

4. 電氮用特種碍子嵫器の㼛究

5. 本邦童屋根瓦の基磞的研究

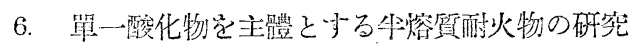

7. セメント混合材及び混合セメントの䂰究

S. 染裝用プラスターの慗浩に閣与る研究

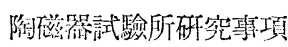




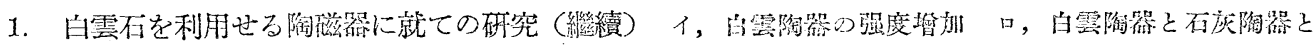

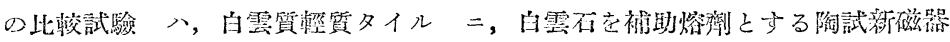

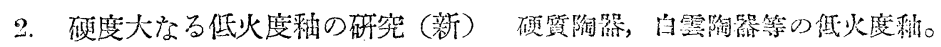

3. 可塑性に關する研究（繼續）４．本邦産べントナイトに關する研究（繼續）

5. 陶嵫器原料脫鐵精製に關子る研究 (繼續)

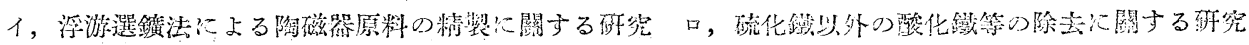

6. 浮游選鏔法に依る陶紐器原料の分離に關するる研究 (新)

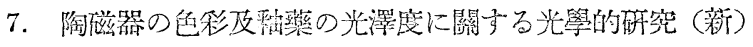

8. 一般领食器用陶隊器の衙慗强度に就ての研究（繼續）

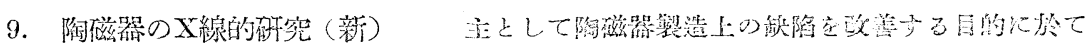

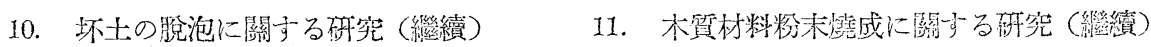

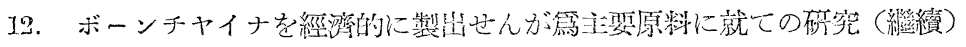

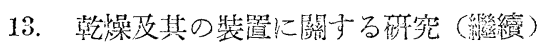

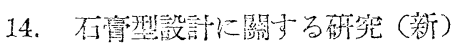

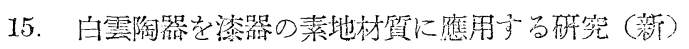

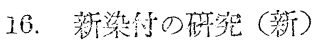

17. 意匠圖案に關与る研究

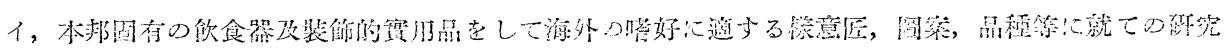

口, 本非钦食器の基碳的研宪

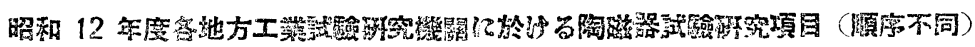

\section{沽㚖縣陶稼器試驗場}

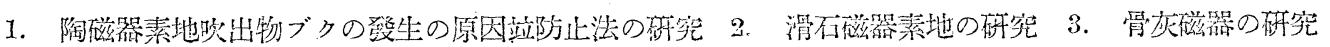

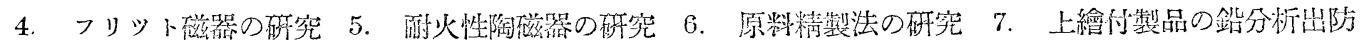

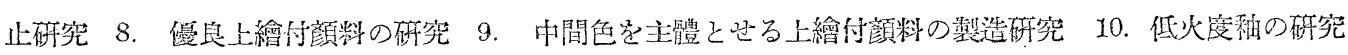

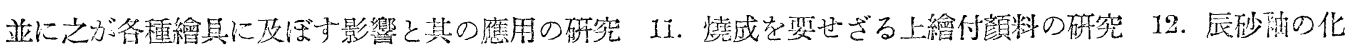

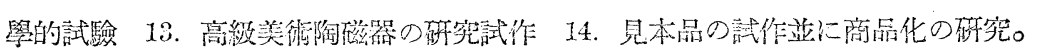
奈息縣工業試驗場

1. 箘業原料翼定試驗

2. 瓦に關する試驗

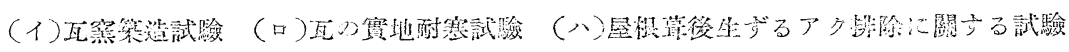
石川縣工㙯指導所

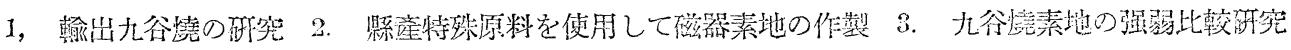

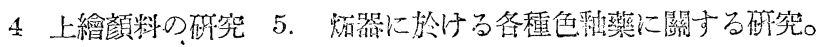
兵庫縣神戶工業試驗場

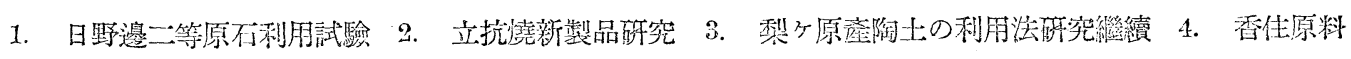
利用事業の助成研究 5. 出不讨副等生产助成研究。 山口縣工業部驗場 


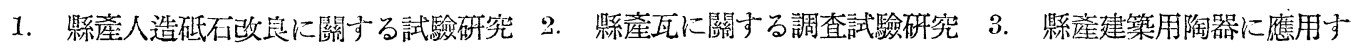
べき着色釉藥站に着色素地の研究 4. 而酸炻器製造上の改良試驗 5 . 萩燒を基調とせる新製品の試作研 究 6. 未開發案業原料の調査站利用研究 7 . 新規考案物の試作 8 . 萩燒に新味を副ふべき加飾方法の 研究試作。

島根糂工業試驗場

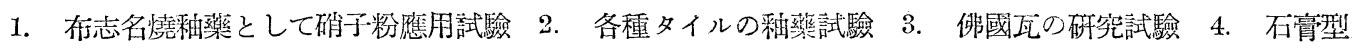
應用工藝品見本製作 5 ．七日市村崖鐵質土の應用試驗 6 ．波多村產陶石の應用試驗。 島根䝮工業試驗場不見分場

1. 海鼠樣色嬏試驗 2. 砂鐵学利用せる瓦租試驗 3. 工業組合統制外の製品研究。 三重影览業試驗場

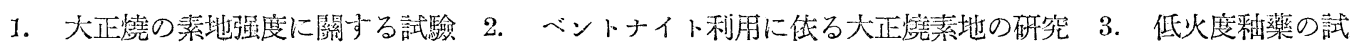

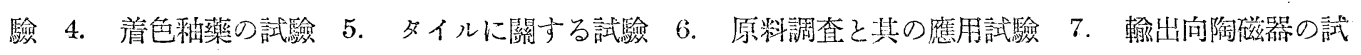

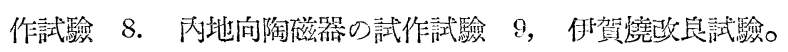
伀賀縣窐業試驗場

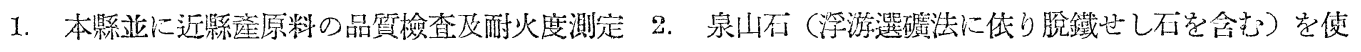

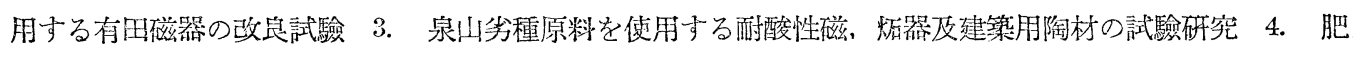

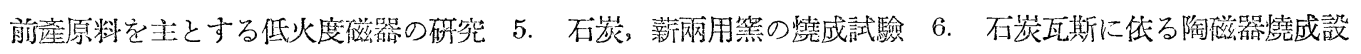

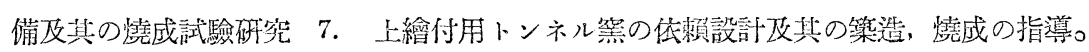
佐賀縣䵫業指導所

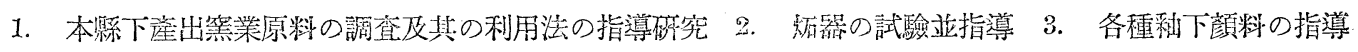

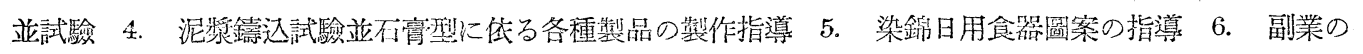
陶傢器製造試驗並指導。

岡山縣工業試驗場

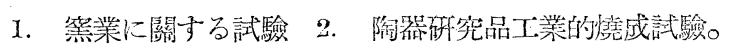
福島縣會津工業試䌞場

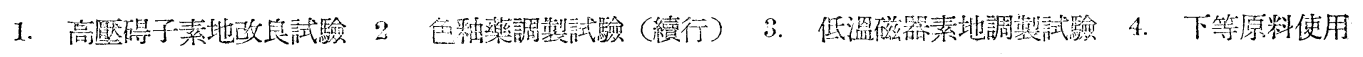

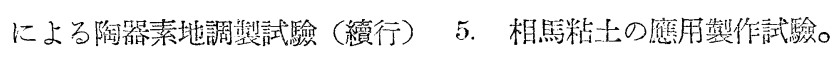

愛知縣工業試驗場

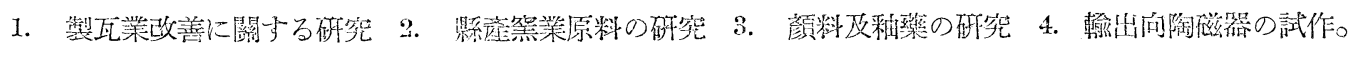
富山㴽工業語驗場

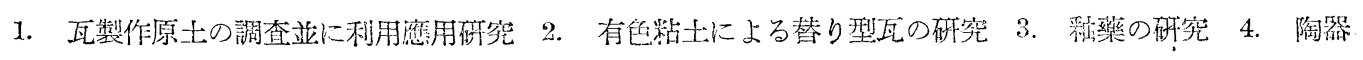
及タイルの研究 5. 燃粼及燒成洷の研究。 北海道工業試驗場

1. 陶藝品試作 2. ベントナイト利用試驗 3. 十勝カリオン利用試驗。 沖繩涼工業指導所

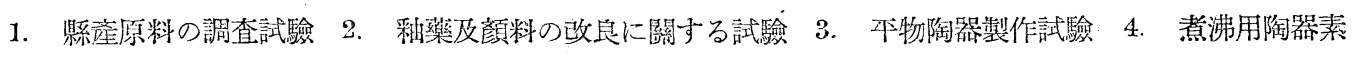


地の研究 5 南蠻燒炻器の改良試驗 6 . 魚骨を用ふる低火度磁器の研究 7. 琉球瓦の改良に關与る試 驗研究 8. 新製品見本の試作試驗。

\section{德島縣工業試驗場}

1. 瓦の變色と使用刷毛上との關係試驗 2. 素燒鈜類加工試驗。 鳥取瀠商工獎的館

1. 瓦燒成用廢寨乏ミ土の利用試驗 2. 瓦燒成用八七の型狀研究 3. 廢萧因幡瓦原档に依る食㯺瓦燒成 試驗 4. 石炭墨に於ける因橎瓦の經濟燒成試驗 5. 來待赤の低溫發色試驗 6. 燒成溫度の冷却速度が

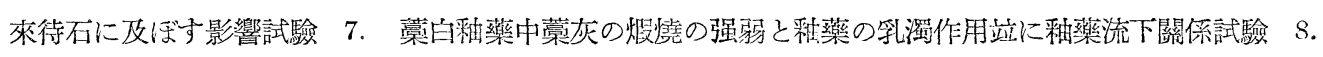

日用品，工藝品の製作試匳 9. 第2號試驗䉆改良試驗。 滋賀縣箘業試驗場

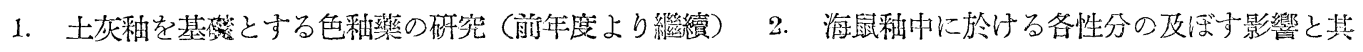

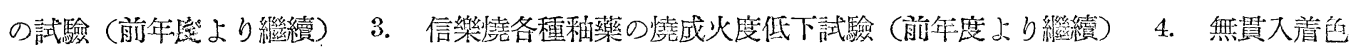

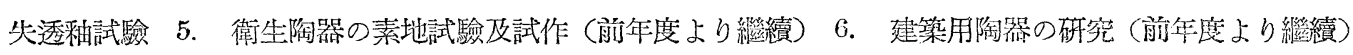

7. 素地改善に依る冷割防止の研究（前年度より繼續）

8. 縣內産各種原料調查站に其の應用試驗（前年度より繼續）

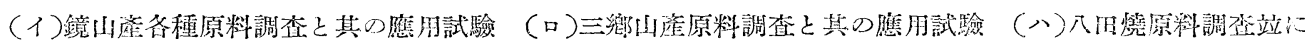
素迆釉攀改良試驗

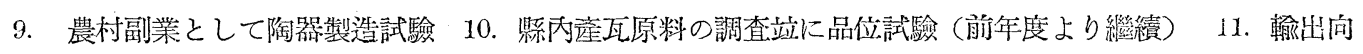
陶器素地釉藥の研究（前年度より繼續） 12. 日本趣味を加味せる洋食器及輸出向新規製品の試作研究（前倞

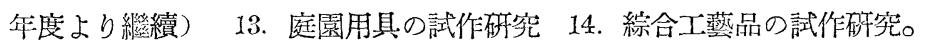

福同南畓業研究所

1. 從來不䢅原料として普通品に使用せられざる原土の利用研究。 大阪市工業研究所

1. 磁器用繪具に紗する研究。 京都市工業研究所

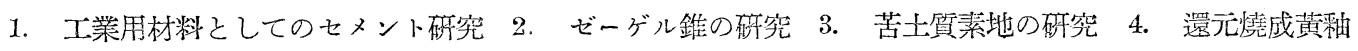

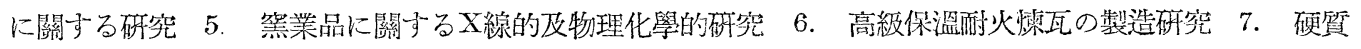
磁器 (默火栓, 磁彆管等)。

荻城縣工藝指導所

1. 縣產原料を以て基本的陶磁器素地の調製研究 2. 縣產原料を以て基本的陶嗞器釉薬の調製研究 3. 縣産タイル素地に適する低火度釉藥の調製研究

4. 陶殍器薄片を木工品に象眼加飾寸る研究

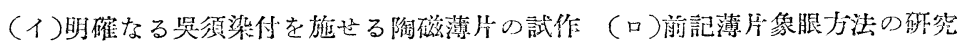

5. 縣峜陶器改善站に製品轉換の研究 6 . 新手法應用に依る鑄込成形の研究。 青森縣工業試驗場

1. 陶土の蒐集湴に試驗 I. 各種陶器の試作涉に製作 3. 意匠圖案の作製 4. 本縣產陶土の化學的研 
究。

長崎縣窒業指導所

1. 土器, 陶器, 䖨器改善研究指導 2 . 縣下陶石の利用試驗 3 . 一般突業原粼調査。

\section{窵の種類に依り燃料を選む必要あり}

熊 溜 治 郎 吉

我國に於ては古來松材を以て堯物穵燒成し來りし事は今更茲に說明寸る迄もないが，明治 30 年の始め頃上 り森材を石炭にて代用する事, 外國の如くせんとし之が研究に着手せし第一人者は故飛鳥井孝太郎氏であつた に相違ない。先生は其研究に大るゃ日夜の區別なく工場に立て籠り隼食を忘れて沒頭せし結果，逐に完成し或 は日本陶器會社又は名古屋製陶所等を產み邆に今日の基礎を造つたといふは決して過言でない。夫れ以前英，

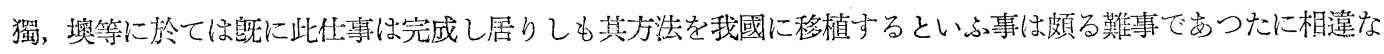
い。其證據としては同氏の最初に研究されし工場地たりし名古屋市撞木町の森村組工場の跡には地下各所に,

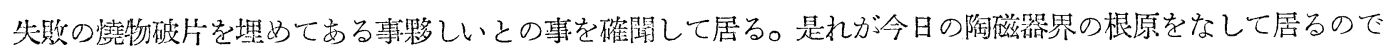
ある。然かも此事實を知つて居る斯界の人は目下既に甚少ないのは誠に遺憾とする所である。

其最初の失敗の主なるものは何であつたかといいば火度の上昇せざりしにあらずして, 石炭より發する火䞍

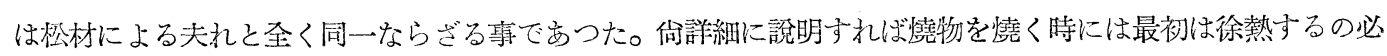

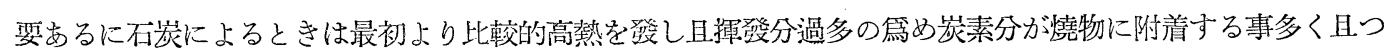
其附着炭素が容易に燃え切れざるが爲め橎藥の愹け始めに害を及湆す缺點ありしと考へる。

之に区し松材を使用するときは最初の火力は弱く徐熱の目的に適し又揮發分は石炭に比し甚少なく燃燒中，

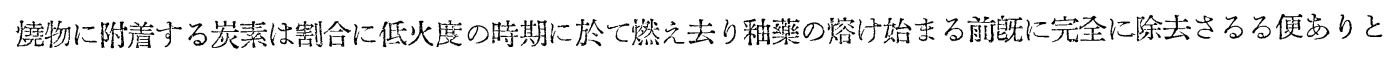
すे

以上の理由を諒解せずして炡成するときは往々失敗を來たするので，笔者の研究したる數多の場合を次に列 擧せば

(i) 酸化䋩により鍩成する場合

陶器類堯成の如くS.K. 8 以下にて酸化熘を以つてする時には石炭によるも何等の失敗を生ずる事がない。

（2）硬質磁器の如くS.K.13 上上に熱する場合其外特に長石質細藥を應用するが如き高熱の場合にも失敗 を招く事がない。

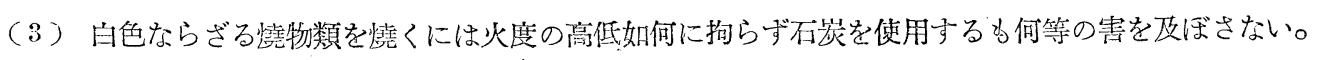

（4）石炭燒成は白色素地なる磁器には害を本ぼす事少なきも酸化コバルトを含める顏料を体用して着畫せ る磁器燒成の場合に於て最も害を與ふる事が大なるが如し。

（5）以上の場合の外，即ち S.K. 9 以上 S.K. 12 番以下なる我國並に支那地方に於て普通磁器㳹成に必要 なる還元燃燒の場合に於て石炭燒成が最も害を及ぼすものである。

其及ぼしたる害とは何なるや，日く素地に施せる釉藥の未だ熔融し始まらざる前に於て，釉藥層並に素地分 